\title{
Putative protective effect of Cadmium chloride high diluted solution on LLC-PK1 cell intoxicated by high concentration of this same metal: an isopathic in vitro assay.
}

\author{
Roberta Ghilosso-Bortolini ${ }^{1}$, Leoni Villano Bonamin ${ }^{2,3}$, Carla Holandino ${ }^{1}$ \\ ${ }^{1}$ Laboratory of Pharmacy Science, Federal University of Rio de Janeiro, Brazil \\ 2 Laboratory of Cellular and Molecular Biology, University Paulista, Brazil \\ ${ }^{3}$ Laboratory Pathology, University of Santo Amaro, Brazil
}

\begin{abstract}
Cadmium is an important toxic environmental heavy metal. Several studies have demonstrated that a major site of cadmium toxicity in humans and in other animals is the proximal tubule of the kidney. A well established model for nefrotoxicity is the use of in vitro technique with proximal tubule epithelial cell lines, as LLC-PK1. Herein, we have the intention to study the possible protective effect of high diluted $\mathrm{CdCl}_{2}$ solutions. In a blinding way, LLC-PK1 cells were pre-treated with high diluted cadmium chloride in the potencies $10 \mathrm{cH}, 15 \mathrm{cH}$ and $20 \mathrm{cH}$. After 4 days, these cells have received $\mathrm{CdCl}_{2}$ in a pre-determined toxic concentration. The cell viability was assessed by MTT assay. We have identified a protective effect of two $\mathrm{CdCl}_{2}$ high diluted solutions, $10 \mathrm{cH}$ and $20 \mathrm{cH}$, when cells were intoxicated by sublethal $\mathrm{CdCl}_{2}$ concentration. The results indicate that probably the high dilutions have an expressive action on cells in sublethal intoxication.
\end{abstract}

Keywords: Cadmium toxicity, High dilution, Isopathy, Cell adaptation, Homeopathy.

\section{Introduction}

Cadmium is an important toxic environmental heavy metal that is commonly related with occupational and environmental pollution mainly in mining, metallurgy industry and manufactures of nickel-cadmium batteries, pigments and plastic stabilizers. Cigarette smoke, food, water and air contaminations are important sources of human intoxication by cadmium that is associated with cancers of the prostate, lungs and testes. At the cellular level, cadmium affects proliferation, differentiation and causes apoptosis. It has been classified as a carcinogen by the International Agency for Research on Cancer (IARC) [1].

As regards to kidney damage, long-term exposure to cadmium via inhalation or ingestion could cause initially minor tubular dysfunctions till severe impairment involving tubuli as well as glomeruli [2]. Studies have documented that a major site of cadmium toxicity in humans and in other animals is the proximal tubule epithelium of the kidney [3], being one of the primary targets of nephrotoxic injury in vivo and much effort has gone into developing in vitro toxicologic models of this particular tissue [4]. 
The proximal tubule model systems that have been developed so far use either primary cultures of proximal tubule epithelial cells or immortal cell lines that were originally derived from proximal tubule epithelium. A wide variety of immortal cell lines derived from various species have been employed: LLC-PK1 (porcine), NRK-52E (rat), OK (opossum) and HK-2 (human) cell lines [4]. LLC-PK1 cells constitute a well established cell line applied in in vitro study model of renal toxicology [5-7], even for Cadmium and other heavy metals toxicity studies [8-10].

In this context, many pharmacological substances have been studied to identify the protective effect on these cells. In 1993, Delbancut and colleagues [11] published an in vitro study model of toxicology in which it was possible to recognize the protective effect of three distinct potencies of high diluted solutions of Cadmium chloride $\left(\mathrm{CdCl}_{2} \mathrm{HD}\right)$. According to these authors, LLC-PK1 cells previously treated with high diluted $\mathrm{CdCl}_{2}$, when in contact with toxic concentration of this same metal, presented a higher cell viability compared to control cells that not received high diluted treatment.

With the aim of reproducing and studying the protective effect of high diluted $\mathrm{CdCl}_{2}$ solutions, we performed an in vitro assay in order to verify the LLC-PK1 response to the high rates of $\mathrm{CdCl}_{2}$.

\section{Materials and Methods}

\section{Cadmium chloride solution}

Cadmium chloride ( $\mathrm{CdCl}_{2}$, Sigma, USA) was dissolved in distilled water at a concentration of $43.79 \mathrm{mM}(1 \%)$, filtered $(0.22 \mu \mathrm{m})$, and stored at $4^{\circ} \mathrm{C}$. Toxic solutions were prepared in distilled water sterilized by filtration. The EC50 (half maximal effective concentration) was obtained with dose-response curve with the following concentrations (in $\mu \mathrm{M}$ ): 10, 30, 100, 300, 1000, 3000 and 10000.

\section{$\mathrm{CdCl}_{2}$ high dilutions}

The $\mathrm{CdCl}_{2}$ high dilutions were prepared according to Brazilian Homeopathic Pharmacopeia [12]. As the metal is a soluble active, the first solution in centesimal scale $(1 \mathrm{cH})$ has concentration of $1 \%$ [13]. The vehicle used was distilled water. In a sterile ambient, freshly $\mathrm{CdCl}_{2}$ solution $(0.23 \mathrm{~g} \mathrm{CdCl} 2$ in $23 \mathrm{ml}$ distilled water $)$ was sterilized by filtration $(0.22 \mu \mathrm{m})$. The quantity of $20 \mathrm{ml}$ was added to a sterile amber flask (capacity for $30 \mathrm{ml}$ ). The same procedure was performed with the control distilled water. At the same time, the two flasks, identified by $\mathrm{CdCl}_{2} \mathrm{HD} 1 \mathrm{cH}$ and Water $\mathrm{HD} 1 \mathrm{cH}$, were placed at the mechanical machine (Denise 10-50, AUTIC) for one hundred sucussions. After, $200 \mu \mathrm{l}$ (one part) of $1 \mathrm{cH}$ was diluted in $19.8 \mathrm{ml}$ (99 parts) of distilled water in amber flask and mechanically agitated, preparing the $2 \mathrm{cH}$. The high dilution preparations were carried out until the $20 \mathrm{cH}$ solutions $\left(\mathrm{CdCl}_{2} \mathrm{HD}\right.$ and Water $\left.\mathrm{HD}\right)$ were reached.

Considering the initial $\mathrm{CdCl}_{2}$ concentration $(1 \mathrm{cH}=1 \mathrm{~g} / 100 \mathrm{ml})$ and Avogadro's constant $\left(6,0221367 \times 10^{23}\right.$ molecules.mol-1), it is possible to calculate the Molar concentration and the expected number of $\mathrm{CdCl}_{2}$ molecules in solution (Table 1).

The $\mathrm{CdCl}_{2} \mathrm{HD}$ solutions tested were $10 \mathrm{cH}, 15 \mathrm{cH}$ and $20 \mathrm{cH}$. The study controls were: distilled water at the same potencies (Water HD $10 \mathrm{cH}, 15 \mathrm{cH}$ and $20 \mathrm{cH}$ ), distilled water without agitation and culture medium. The blindness of the experiment was conducted as follow: all flasks, containing high dilutions or controls, received a label with solution identification. Two colleagues, not directly related to the project, changed the identification label by another with a number identification (1 to 8). The first labels were placed in a paper with the related number. The two scientists signed the blindness proceeding, and the paper was placed in an envelope and then sealed. After statistical analysis of the results, the enveloped was opened. 
Table 1. Molar Concentration of $\mathrm{CdCl}_{2} \mathrm{HD}$ solutions and Avogadro's constant.

\begin{tabular}{|l|l|l|}
\hline $\mathbf{C d C l}_{2} \mathbf{H D}$ & Molar Concentration (M) & $\begin{array}{l}\text { Avogadro Constant } \\
\mathbf{( 6 , 0 2 2} \times \mathbf{1 0}^{23} \text { molecules/ mol) }\end{array}$ \\
\hline $1 \mathrm{cH}$ & $\mathrm{CdCl}_{2} 1 \%=0,05 \mathrm{M}$ & $0,30115 \times 10^{23}$ \\
\hline $2 \mathrm{cH}$ & $5 \times 10^{-4}$ & $3,0115 \times 10^{20}$ \\
\hline $3 \mathrm{cH}$ & $5 \times 10^{-6}$ & $3,0115 \times 10^{18}$ \\
\hline $4 \mathrm{cH}$ & $5 \times 10^{-8}$ & $3,0115 \times 10^{16}$ \\
\hline $5 \mathrm{cH}$ to $9 \mathrm{cH}$ & $5 \times 10^{-10}$ to $5 \times 10^{-18}$ & $3,0115 \times 10^{14}$ to $3,0115 \times 10^{6}$ \\
\hline$* \mathbf{1 0} \mathbf{c H}$ & $5 \times 10^{-20}$ & $3,0115 \times 10^{4}$ \\
\hline $11 \mathbf{c H}$ & $5 \times 10^{-22}$ & $3,0115 \times 10^{2}$ \\
\hline $12 \mathbf{c H}$ & $5 \times 10^{-24}$ & $3,0115 \times 10^{0}$ \\
\hline $13 \mathbf{c H}$ & $5 \times 10^{-26}$ & $3,0115 \times 10^{-2}$ \\
\hline $14 \mathbf{c H}$ & $5 \times 10^{-28}$ & $3,0115 \times 10^{-4}$ \\
\hline$* \mathbf{1 5} \mathbf{c H}$ & $\mathbf{5} \times \mathbf{1 0}^{-30}$ & $\mathbf{3 , 0 1 1 5 \times 1 0 ^ { - 6 }}$ \\
\hline $16 \mathbf{c H}$ to $19 \mathrm{cH}$ & $5 \times 10^{-32}$ to $5 \times 10^{-38}$ & $3,0115 \times 10^{-8}$ to $3,0115 \times 10^{-14}$ \\
\hline$* \mathbf{2 0} \mathbf{c H}$ & $\mathbf{5 \times 1 0 ^ { - 4 0 }}$ & $\mathbf{3 , 0 1 1 5 \times 1 0 ^ { - 1 6 }}$ \\
\hline & & \\
\hline
\end{tabular}

* Potencies tested in the present study.

\section{Cell culture}

LLC-PK1 cells originating from pig proximal tubule (obtained at Federal University of Rio de Janeiro, Brazil) were routinely grown in a monolayer culture in the presence of Dulbecco's modified Eagle's medium (DMEM) supplemented with $10 \%$ of heat-inactivated fetal bovine serum (FBS), $100 \mathrm{U} / \mathrm{ml}$ penicillin and $100 \mathrm{mg} / \mathrm{ml}$ streptomycin, in plastic cell culture flask, in incubator at $37^{\circ} \mathrm{C}$. The medium was replaced and the cells were trypsinised and splited three times a week. The cells were transferred into 96 -well culture plate for cytotoxicity assay.

\section{Cell viability test: Colorimetric MTT (tetrazolium) assay}

The cell viability of control and treated cultures were assessed by MTT assay, a sensitive and quantitative colorimetric assay, that measures viability based on the capacity of mitochondrial succinyl dehydrogenase in living cells to convert the yellow substrate Thiazolyl Blue Tetrazolium Bromide (MTT, Sigma) into a dark blue formazan product. At the end of the experiment, MTT solution (final concentration of $0.5 \mathrm{or} 1 \mathrm{mg} / \mathrm{ml} \mathrm{in}$ phosphate- buffered saline - PBS) was added to all wells, and the plate was incubated at $37^{\circ} \mathrm{C}$ for $4 \mathrm{~h}$. After, in each well, the medium was removed, and the formazan (dark blue crystals) were extracted from the intact cells with dimethyl sulfoxide (DMSO) and mixed thoroughly to dissolve them. The quantity of formazan is directly proportional to the living cell number measured. The absorbance was determined using a scanning spectrophotometer (540 nm against $630 \mathrm{~nm}$ as reference) [14-16]. 


\section{Cytotoxicity assay}

The assay lasted a total of 7 days, 168 hours [11]. The figure 1 shows a general scheme of the assay for the experimental group $\mathrm{CdCl}_{2} \mathrm{HD}$ (one well representation). On day zero, the LLC-PK1 cells were added to a 96well, flat bottom, tissue culture plate at the density of $3 \times 10^{6}$ cells or $4 \times 10^{6}$ cells per well in 5\% FBS DMEM medium. On day 1, twenty four hours after seeding, LLC-PK1 cells were exposed to $\mathrm{CdCl}_{2} \mathrm{HD}(10 \mathrm{cH}, 15 \mathrm{cH}$ or $20 \mathrm{cH})$, or Water $\mathrm{HD}(10 \mathrm{cH}, 15 \mathrm{cH}$ or $20 \mathrm{cH})$, or distilled water with no agitation or culture medium (DMEM). All then added with the same volume; 1:10 dilution in culture medium into well. On day 6, after 144 hours, a toxic concentration of $\mathrm{CdCl}_{2}$ was added and the cell viability was determined after $24 \mathrm{~h}$ by colorimetric MTT assay.

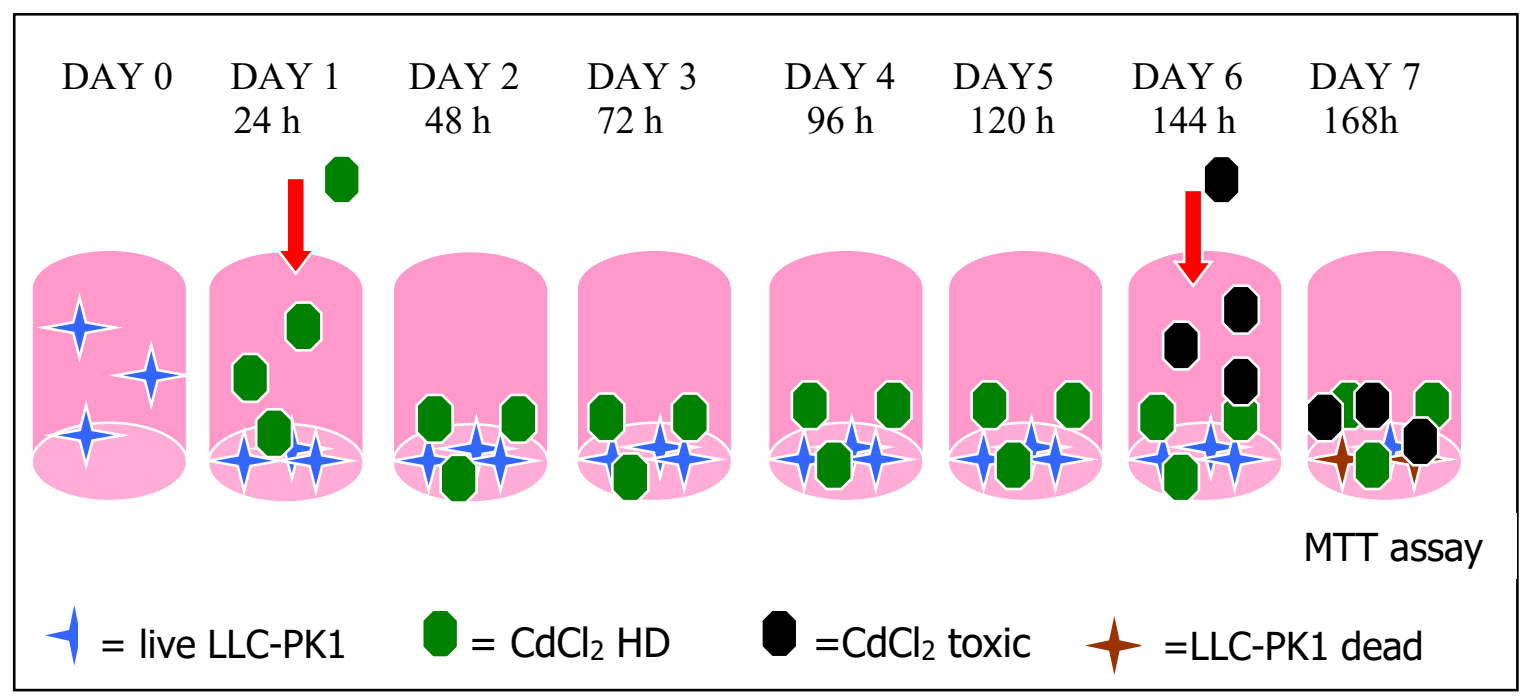

Figure 1. A general scheme of the citotoxicity assay for the experimental group $\mathrm{CdCl}_{2} \mathrm{HD}$ (one well representation). On day zero, the LLC-PK1 cells were added to the plate. On day 1, twenty four hours after seeding, LLC-PK1 cells were exposed to $\mathrm{CdCl}_{2} \mathrm{HD}$. On day 6, a toxic concentration of $\mathrm{CdCl}_{2}$ was added and the cell viability was determined after $24 \mathrm{~h}$ by colorimetric MTT assay.

Regards to the study controls, Water HD $(10 \mathrm{cH}, 15 \mathrm{cH}$ or $20 \mathrm{cH})$, distilled water with no agitation and culture medium (DMEM), they were exposed to toxic $\mathrm{CdCl}_{2}$ concentration also. The table 2 shows the details of the experimental and study control groups (total of 16 groups: with or without $\mathrm{CdCl}_{2}$ toxic concentration) and explanation about each group research intention.

As the study was done in a blinding way, the groups were identified by numbers, and each number group was or not in the presence of the toxic Cadmium solution. A very similar distribution of the groups on the 96-wellplate was displayed: columns 1 to 6 , cells that have not received the metal toxic concentration, and columns 7 12 , cells that have received it. As the experiment lasted 144 hours, it is important to take into consideration the possible medium evaporation. Buckberry [17] suggests to avoid columns (1-12) and lines (A and H) as they experience slightly different growth conditions and so they are not used for testing. In this assay, it was necessary to use some of them: all groups (numbers) were distributed on plate, in quintuplicate, except on the corners - $(1 \mathrm{~A}, 2 \mathrm{~A}, 1 \mathrm{~B}, 1 \mathrm{C} ; 11 \mathrm{~A}, 12 \mathrm{~A}, 12 \mathrm{~B}, 12 \mathrm{C} ; 1 \mathrm{~F}, 1 \mathrm{G}, 1 \mathrm{H}, 2 \mathrm{H} ; 11 \mathrm{H}, 12 \mathrm{H}, 12 \mathrm{G}, 12 \mathrm{~F})$ where sterile water was added.

Table 2. Experimental groups and their respective research intention. 
Table 2. Experimental groups and their respective research intention.

\begin{tabular}{|c|c|c|c|c|}
\hline cell & added substance & Group name & $\begin{array}{l}\mathrm{CdCl}_{2} \text { toxic } \\
\text { concentration }\end{array}$ & Research intention Identification of: \\
\hline \multirow[t]{2}{*}{ LLC-PK1 } & \multirow[t]{2}{*}{+ medium } & \multirow[t]{2}{*}{ Medium } & + Medium & $\begin{array}{l}\text { * quantitative value for total cell live } \\
(100 \% \text { viability) }\end{array}$ \\
\hline & & & $+\mathrm{CdCl}_{2}$ & * quantitative value for total cell death \\
\hline \multirow[t]{2}{*}{ LLC-PK1 } & \multirow[t]{2}{*}{$\begin{array}{l}+ \text { distilled water } \\
\text { with no agitation }\end{array}$} & \multirow[t]{2}{*}{ Water } & + Medium & $\begin{array}{l}\text { * any difference in cell viability due to } \\
\text { osmolarity change (not seen in Medium } \\
\text { group) } \\
\text { * water HD control }\end{array}$ \\
\hline & & & $+\mathrm{CdCl}_{2}$ & * control \\
\hline \multirow[t]{2}{*}{ LLC-PK1 } & \multirow{2}{*}{$\begin{array}{l}+\mathrm{CdCl} 210 \mathrm{cH} \text { or } \\
15 \mathrm{cH} \text { or } 20 \mathrm{cH}\end{array}$} & \multirow{2}{*}{$\begin{array}{l}\mathrm{CdCl} 210 \mathrm{cH} \text { or } \\
15 \mathrm{cH} \text { or } 20 \mathrm{cH}\end{array}$} & + Medium & $\begin{array}{l}\text { * any biological effect as proliferation, } \\
\text { suppression or cell death. }\end{array}$ \\
\hline & & & $+\mathrm{CdCl}_{2}$ & * protective effect \\
\hline \multirow[t]{2}{*}{ LLC-PK1 } & \multirow{2}{*}{$\begin{array}{l}\text { + Water } 10 \mathrm{cH} \text { or } \\
15 \mathrm{cH} \text { or } 20 \mathrm{cH}\end{array}$} & \multirow{2}{*}{$\begin{array}{l}\text { Water } 10 \mathrm{cH} \text { or } \\
15 \mathrm{cH} \text { or } 20 \mathrm{cH}\end{array}$} & + Medium & $\begin{array}{l}\text { * any biological effect as proliferation, } \\
\text { suppression or cell death. }\end{array}$ \\
\hline & & & $+\mathrm{CdCl}_{2}$ & * control \\
\hline
\end{tabular}

The figure 2 presents this distribution, as in a mirror image configuration. This very similar group position on plate have allowed a most similar condition cells growth, considering a possible medium evaporation, in order to have an appropriate comparison of results.

\begin{tabular}{|l|l|l|l|l|l|l|l|l|l|l|l|l|}
\hline & $\mathbf{1}$ & $\mathbf{2}$ & $\mathbf{3}$ & $\mathbf{4}$ & $\mathbf{5}$ & $\mathbf{6}$ & $\mathbf{7}$ & $\mathbf{8}$ & $\mathbf{9}$ & $\mathbf{1 0}$ & $\mathbf{1 1}$ & $\mathbf{1 2}$ \\
\hline A & & & 2 & 3 & 4 & 5 & 5 & 4 & 3 & 2 & & \\
\hline B & & 1 & 2 & 3 & 4 & 5 & 5 & 4 & 3 & 2 & 1 & \\
\hline C & & 1 & 2 & 3 & 4 & 5 & 5 & 4 & 3 & 2 & 1 & \\
\hline D & 1 & 1 & 2 & 3 & 4 & 5 & 5 & 4 & 3 & 2 & 1 & 1 \\
\hline E & 6 & 1 & 2 & 3 & 4 & 5 & 5 & 4 & 3 & 2 & 1 & 6 \\
\hline F & & 6 & 6 & 7 & 7 & 8 & 8 & 7 & 7 & 6 & 6 & \\
\hline G & & 6 & 6 & 7 & 8 & 8 & 8 & 8 & 7 & 6 & 6 & \\
\hline H & & & 7 & 7 & 8 & 8 & 8 & 8 & 7 & 7 & & \\
\hline
\end{tabular}

Figure 2. Illustration of the groups (identified by numbers in a blinding way) distribution on a 96 well plate. The plate corners were avoided, and distribution presents a mirror image configuration. Columns 1 to 6 , cells that have not received the metal toxic concentration, and columns 7-12, cells that have received it. 


\section{Statistics}

Results were expressed as mean \pm SD. Data were from quintuplicate samples $(n=5)$, the quantity of experiments is informed on the graphic legend and text. The statistical significance was determined by OneWay Anova followed by Tukey test. $\mathrm{P}<0.05$ was considered statistically significant.

\section{Results}

As usually, every new protocol in a laboratory has to pass throughout standardization process. In this case, initially the number of cell per well and the MTT solution concentration were determined.

\section{Standardization: number of cell per well and MTT solution concentration}

Exponentially growing LLC-PK1 cells were plated at density of $1 \times 10^{3}, 2 \times 10^{3}, 3 \times 10^{3}, 4 \times 10^{3}, 5 \times 10^{3}$ and $6 \times 10^{3}$ per well in 96 -well, flat bottom, tissue culture plate, 10 wells per density cell, and cultured for 7 day. The cell viability was assessed by MTT assay, which was standardized too, concerning the MTT solution concentration for appropriate identification of LLC-PK1 cell line viability, as the quantity of mitochondrial succinyl dehydrogenase vary in cell lines [18-19]. In addition, the quantity of formazan produced per cell in a given time is dependent on the metabolic activity of the cell [20]. Then, in this same plate, the number of cell per well and the MTT final concentrations $-0.5 \mathrm{mg} / \mathrm{ml}$ and $1 \mathrm{mg} / \mathrm{ml}$ in PBS [19] were tested ( $\mathrm{n}=5$ wells per MTT solution, in each density cell). This experiment has allowed the identification of a relationship between cell number and optical density in LLC-PK1 cells. The acceptable colorimetric profile should have absorbance > 0.500 [19]. The figure 3 presents a graphic relating optical density and cell number $\left(\mathrm{x} 10^{3}\right)$.
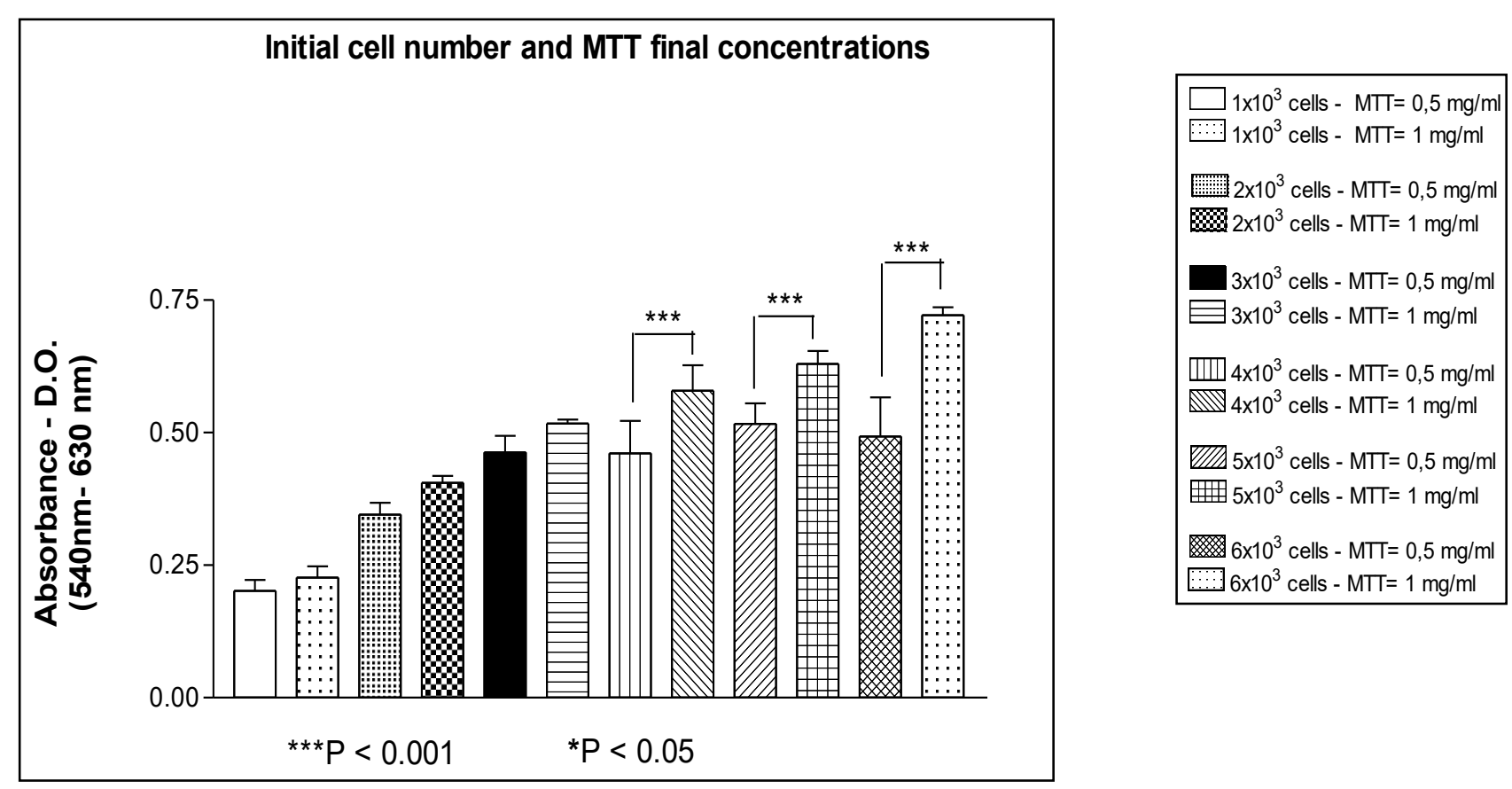

Figure 3. Number of cell per well and viability (optical density) assessed by MTT assay. The initial cell number $1 \times 10^{3}, 2 \times 10^{3}, 3 \times 10^{3}, 4 \times 10^{3}, 5 \times 10^{3}$ and $6 \times 10^{3}$ per well were grown for 7 days. The MTT final concentrations $0.5 \mathrm{mg} / \mathrm{ml}$ and $1 \mathrm{mg} / \mathrm{ml}$ were tested. Data are from one experiment, $\mathrm{n}=5$ per group. ${ }^{*} \mathrm{P}<0.05,{ }^{* *} \mathrm{P}<0.01,{ }^{* * *} \mathrm{P}<0.001$.

The figure 3 describes the relationship between cell number and optical density. The density cell started at 3 x $10^{3}$ cells has presented an absorbance value closed or superior to 0.500 . There was no statistical difference 
between the absorbance value of the cell group $3 \times 10^{3}$ when they have received the MTT final concentrations of 0.5 or $1 \mathrm{mg} / \mathrm{ml}$. However, the groups $4 \times 10^{3}, 5 \times 10^{3}$ and $6 \times 10^{3}$ cells have shown a significant statistical difference $(\mathrm{P}<0.001)$. With these results, the initial cell number per well determined to be used on citotoxicity assay were: $3 \times 10^{3}$ and $4 \times 10^{3}$ cells. This because cell viability with basal absorbance value near to 0.500 when receiving a substance with a possible proliferation cell effect in an assay can have an absorbance increase within the ideal absorbance for MTT assay (absorbance between 0.2 to 0.9 ). And also, it was determined the MTT final concentration of $0.5 \mathrm{mg} / \mathrm{ml}$.

\section{Half maximal effective concentration (EC50) of $\mathrm{CdCl}_{2}$ on LLCPK1 cells during 24 hours}

The $\mathrm{CdCl}_{2}$ concentration which induced a response halfway between the baseline and maximum, after 24 hours of exposure, on LLC-PK1 cells, the half maximal effective concentration $\left(\mathrm{EC}_{50}\right)$, is presented in a sigmoid dose response curve (figure 4) [21].

For that, the $\mathrm{CdCl}_{2}$ concentrations $10 \mu \mathrm{M}, 30 \mu \mathrm{M}, 100 \mu \mathrm{M}, 300 \mu \mathrm{M}, 1000 \mu \mathrm{M}, 3000 \mu \mathrm{M}$ and $10000 \mu \mathrm{M}$, were added to LLC-PK1 cells at day 6 of culture growing. The dilution was 1:10 in culture medium, then the $\mathrm{CdCl}_{2}$ final concentrations were $1 \mu \mathrm{M}, 3 \mu \mathrm{M}, 10 \mu \mathrm{M}, 30 \mu \mathrm{M}, 100 \mu \mathrm{M}, 300 \mu \mathrm{M}$ and $1000 \mu \mathrm{M}$. These were plotted on dose response curve. The initial density cells was $3 \times 10^{3}$. The cell viability was measured by MTT assay. According to the sigmoid dose-response curve the EC50 value is 73,31 $\pm 7,9 \mu \mathrm{M}$.

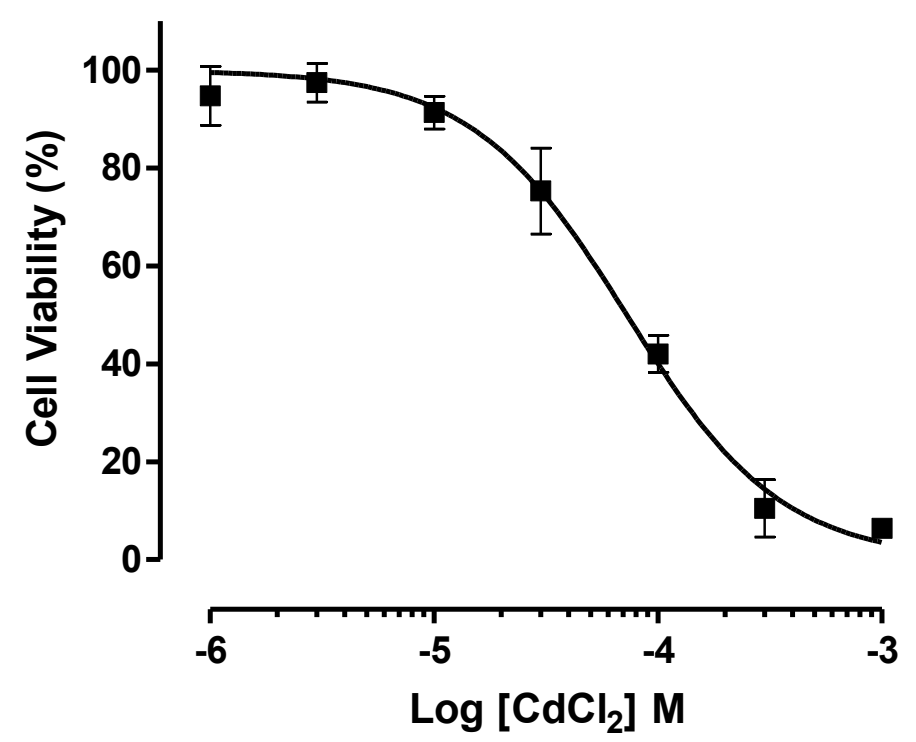

Figure 4. EC50 of $\mathrm{CdCl}_{2}$ on LLC-PK1 cells during 24 hours. Effect of the final concentrations 1 $\mu \mathrm{M}, 3 \mu \mathrm{M}, 10 \mu \mathrm{M}, 30 \mu \mathrm{M}, 100 \mu \mathrm{M}, 300 \mu \mathrm{M}$ and $1000 \mu \mathrm{M}$ on LLC-PK1 cell viability assessed by MTT assay. EC50 value is 73,31 $\pm 7,9 \mu \mathrm{M}$. EC50 and EC25, represent cadmium concentrations needed to kill 50 and 25\%, respectively, of a cell population. Data represent the mean of three independent experiments ( $\mathrm{n}=5$ wells/experiment). Only the concentration $1000 \mu \mathrm{M}$ was tested in two experiments.

\section{Citotoxicity assay}


According to the protocol suggested by Delbancut and colleagues [11], we have performed the citotoxicity assay as described in detail in materials and methods. On day 1 , after 24 hours of cell seeding ( $4 \times 10^{3}$ cells), the $\mathrm{CdCl}_{2}$ potencies $10 \mathrm{cH}, 15 \mathrm{cH}$ and $20 \mathrm{cH}$ were added as well as the controls: water high diluted (Water HD10 $\mathrm{cH}, 15 \mathrm{cH}$ or $20 \mathrm{cH}$ ), distilled water with no agitation and culture medium (DMEM). On day 6, the cells groups have received a toxic $\mathrm{CdCl}_{2}$ solution $(\mathrm{EC} 25=38 \mu \mathrm{M})$. After 24 hours of the metal intoxication, the cell viability was assessed by MTT assay (figure 5).

\section{$\mathrm{CdCl}_{2}$ UHD Effect on LLC-PK1 viability}

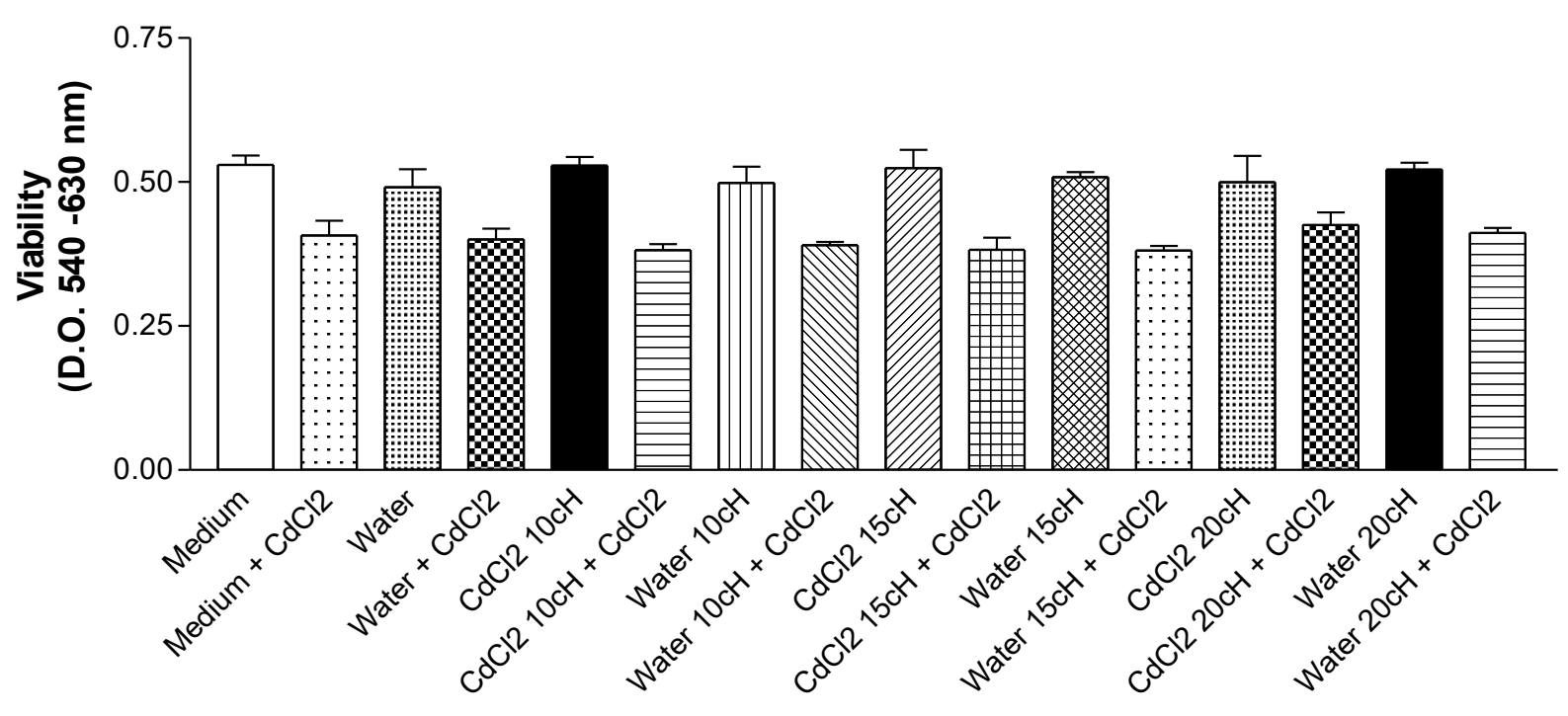

Figure 5. Citotoxicity assay to detect potential $\mathrm{CdCl}_{2} \mathrm{HD}$ protection effect on intoxicated LLCPK1 cells. The quantity of $4 \times 10^{3}$ cells, after 24 hour, have received: $\mathrm{CdCl}_{2} \mathrm{HD}(10 \mathrm{cH}, 15 \mathrm{cH}$ or 20 $\mathrm{cH})$, or Water HD $(10 \mathrm{cH}, 15 \mathrm{cH}$ or $20 \mathrm{cH})$, or distilled water with no agitation or culture medium, respectively. On day 6 , the cells groups have received a toxic $\mathrm{CdCl}_{2}$ solution $(\mathrm{EC} 25=38 \mu \mathrm{M})$. After 24 hours of the metal intoxication, the cell viability was defined by MTT assay. Data from 1 experiment, 5 wells per group.

The data presented on figure 5 show that there were statistical difference between groups which have received the solutions $\left(\mathrm{CdCl}_{2} \mathrm{HD}\right.$ or water $\mathrm{HD}$ (potencies $10 \mathrm{cH}, 15 \mathrm{cH}$ or $20 \mathrm{cH}$ ) or distilled water with no agitation or culture medium) with no metal intoxication in comparison with the groups that were intoxicated. As a result, there was no evidence of protective $\mathrm{CdCl}_{2} \mathrm{HD}$ effect as observed in other experiments (data not shown).

Due to lack of evidence, after reviewing data, it was decided to change the protocol: the cells would receive two test solution or control stimulus- first on day 1, and second on day 4. The next experiment was performed as following described: $3 \times 10^{3}$ cells, after seeding $(24 \mathrm{~h})$, have received freshly prepared solutions $\left(\mathrm{CdCl}_{2} 10 \mathrm{cH}\right.$, $15 \mathrm{cH}$ or $20 \mathrm{cH}$, Water $10 \mathrm{cH}, 15 \mathrm{cH}$ or $20 \mathrm{cH}$, distilled water with no agitation or culture medium) on day 1 and 4. On day 6 , the cells groups have received a toxic $\mathrm{CdCl}_{2}$ solution $(\mathrm{EC} 25=38 \mu \mathrm{M})$. After 24 hours of the metal intoxication, the cell viability was assessed by MTT assay (figure 6). 


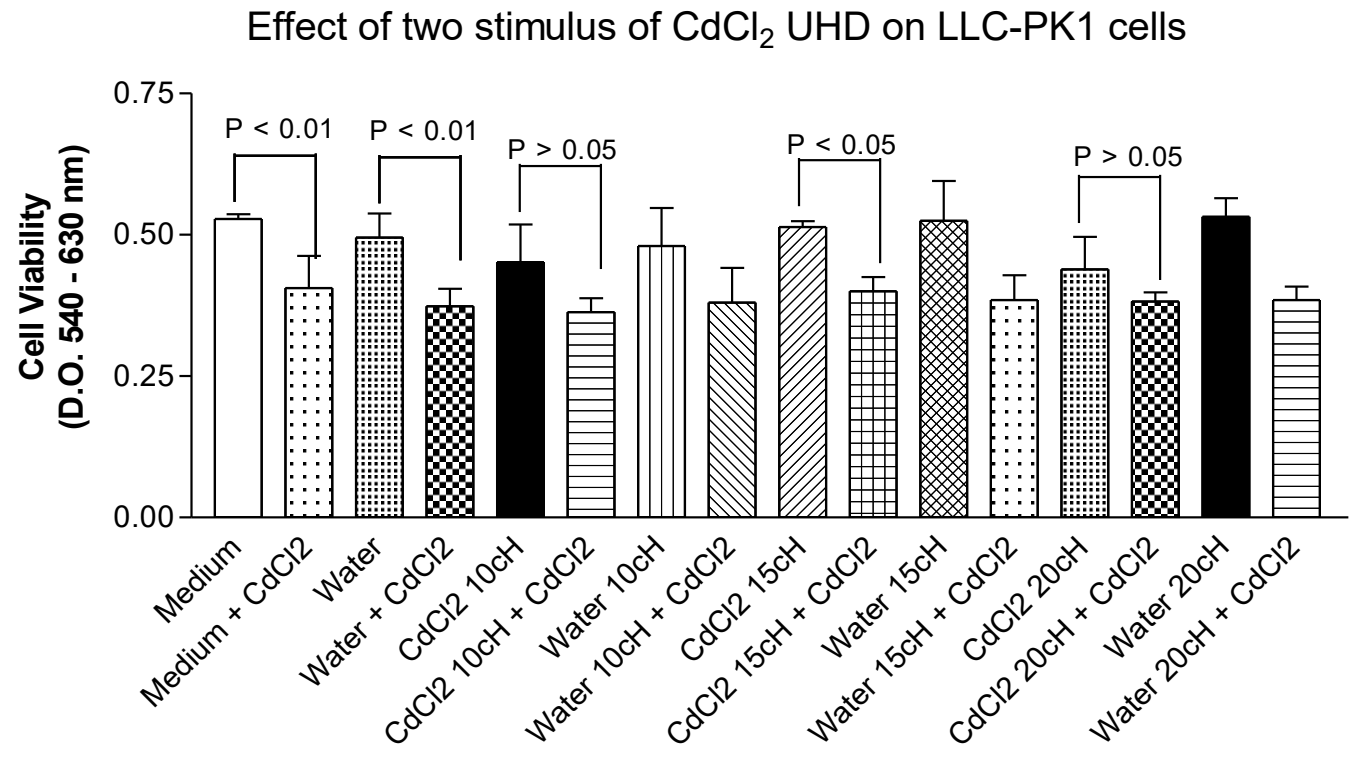

Figure 6. Citotoxicity assay to detect potential $\mathrm{CdCl}_{2} \mathrm{HD}$ protection effect on intoxicated LLCPK1 cells that received two stimulus. The quantity of $3 \times 10^{3}$ cells, after 24 hour, have received: $\mathrm{CdCl}_{2} \mathrm{HD}(10 \mathrm{cH}, 15 \mathrm{cH}$ or $20 \mathrm{cH})$, or Water $\mathrm{HD}(10 \mathrm{cH}, 15 \mathrm{cH}$ or $20 \mathrm{cH})$, or distilled water with no agitation or culture medium, respectively, on day 1 and 4 . On day 6 , the cells groups have received a toxic $\mathrm{CdCl}_{2}$ solution $(\mathrm{EC} 25=38 \mu \mathrm{M})$. After 24 hours of the metal intoxication, the cell viability was defined by MTT assay. Data from 1 experiment, 5 wells per group.

The statistical analysis of the results have shown that the control groups water and medium versus water and medium intoxicated, respectively, had statistical difference $(\mathrm{P}<0.01)$. In addition, the group $\mathrm{CdCl}_{2} 15 \mathrm{cH}$ versus $\mathrm{CdCl}_{2} 15 \mathrm{cH}+\mathrm{CdCl}_{2}$ toxic concentration $(\mathrm{EC} 25=38 \mu \mathrm{M})$ have presented statistical difference $(\mathrm{P}<0.05)$. On the other hand, the groups $\mathrm{CdCl}_{2} 10 \mathrm{cH}$ versus $\mathrm{CdCl}_{2} 10 \mathrm{cH}+\mathrm{CdCl}_{2}$ toxic concentration $(\mathrm{EC} 25=38 \mu \mathrm{M})$ and $\mathrm{CdCl}_{2} 20 \mathrm{cH}$ versus $\mathrm{CdCl}_{2} 20 \mathrm{cH}+\mathrm{CdCl}_{2}$ toxic concentration $(\mathrm{EC} 25=38 \mu \mathrm{M}$ ) have not presented statistical difference $(\mathrm{P}>0.05)$. This blinding assay allows to verify that $\mathrm{CdCl}_{2} 10 \mathrm{cH}$ and $\mathrm{CdCl}_{2} 20 \mathrm{cH}$ had protective effect on LLC-PK1 cells that have received toxic concentration of this same metal. However, the same experiment protocol and solutions where tested twice, in a blinding way, and there was no protective effect observed (data not shown).

With the intention to discern the $\mathrm{CdCl}_{2} \mathrm{HD}$ protective effect, the next step was to triggered cells with double metal toxic concentration $(\mathrm{EC} 50=73 \mu \mathrm{M})$. The results are displayed on figure 7 .

Unfortunately, it was not possible to distinguish the protective effect of $\mathrm{CdCl}_{2} \mathrm{HD}$ on LLC-PK1 cells when they have received EC50 metal concentration.

In sum, only one experiment presented a protective effect as illustrated on figure 6: freshly solutions tested, initial cell number of $3 \times 10^{3}, \mathrm{EC} 25=38 \mu \mathrm{M}$. This was considered approved, as the experiment was well established, the variables (as a possible difference between groups concerning the cell growing) were managed and it was performed in a blinding way. 


\section{Effect of two stimulus of $\mathrm{CdCl}_{2}$ UHD on LLC-PK1}

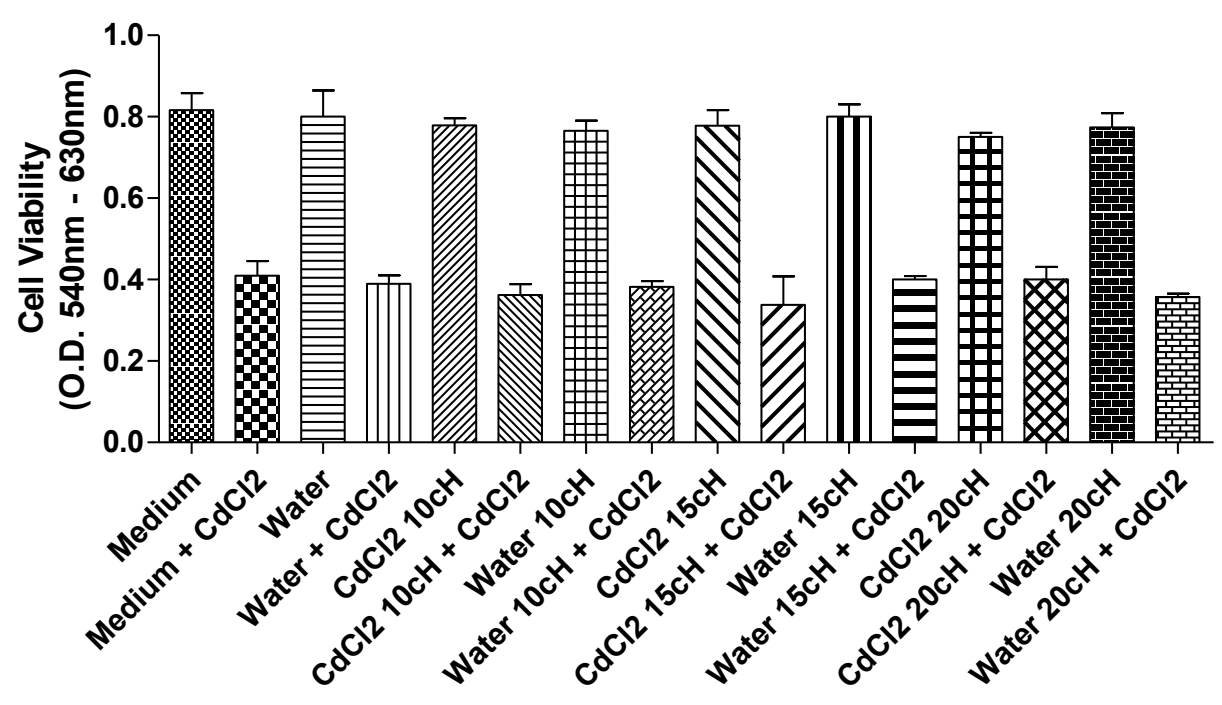

Figure 7. Citotoxicity assay to detect potential $\mathrm{CdCl}_{2} \mathrm{HD}$ protection effect on intoxicated LLCPK1 cells that have received two stimulus. The quantity of $3 \times 10^{3}$ cells, after 24 hour, have received: $\mathrm{CdCl}_{2} \mathrm{HD}(10 \mathrm{cH}, 15 \mathrm{cH}$ or $20 \mathrm{cH})$, or Water $\mathrm{HD}(10 \mathrm{cH}, 15 \mathrm{cH}$ or $20 \mathrm{cH})$, or distilled water with no agitation or culture medium, respectively, on day 1 and 4 . On day 6 , the cells groups have received a toxic $\mathrm{CdCl}_{2}$ solution $(\mathrm{EC} 50=73 \mu \mathrm{M})$. After 24 hours of the metal intoxication, the cell viability was defined by MTT assay. Data from 1 experiment, 5 wells per group. Representative of two experiments.

\section{Discussion}

The well established in vitro citotoxicity technique is a useful tool for pharmacological investigations even for high diluted solutions. Delbancut and colleagues [11] performed an experiment aiming to identify the protective effect of $\mathrm{CdCl}_{2}$ high diluted solution on pig proximal tubule epithelial cells, LLC-PK1 cells, when these cells were exposed to toxic concentration of this metal. The high diluted $\mathrm{CdCl}_{2}$ solutions $10^{-20}, 10^{-30}$ e $10^{-}$ ${ }^{40} \mathrm{M}$ (corresponding almost to $10 \mathrm{cH}, 15 \mathrm{cH}$ and $20 \mathrm{cH}$ ) were prepared in culture medium and by a serial of centesimal dilutions. Each dilution was agitated in vortex for 30 seconds. The control was culture medium agitated in vortex for 30 seconds also. The experimental model was: LLC-PK1 cells, at the density of $4 \times 10^{3}$ cells per well were placed in a 96-well plate. On day 1, after cell seeding, the cells were exposed to high diluted $\mathrm{CdCl}_{2}$ solutions $10^{-20}, 10^{-30}, 10^{-40} \mathrm{M}$ or control (medium agitated). The pre-treatment lasted 120 hours. On day 6, the cells were intoxicated by $\mathrm{CdCl}_{2}$ at concentrations of $2,3,3.5,4$ and $5 \times 10^{-5} \mathrm{M}$ for 24 hours. The method used to assess the cell viability was neutral red. In these experimental conditions, the authors identified the protective effect of the three high diluted solutions studied.

The present work had the intention to reproduce and to study the protective effect of high diluted $\mathrm{CdCl}_{2}$ solutions. For that, some adaptations were determined: the use of water as vehicle of the HD solutions (with the intention to avoid dinamization of the medium culture constituents), the use of mechanical agitation instead of vortex, the controls water and medium were not agitated. For determination of $\mathrm{CdCl}_{2}$ toxic concentration, it was performed an EC50 dose-response curve, and comparing with the other authors results, the values were not similar: $2 \times 10^{-5} \mathrm{M}$ in Delbancut and colleagues study [11] and 7,3 x $10^{-5} \mathrm{M}$ in this study. This discrepancy might be due to laboratory variables related to different conditions in culture cell technique. The present study did not identified the protective effect of $\mathrm{CdCl}_{2} 15 \mathrm{cH}$, only in $10 \mathrm{cH}$ and $20 \mathrm{cH}$ when intoxicated by sublethal $\mathrm{CdCl}_{2}$ dose. 
Reviewing the complete data, two important facts should be pointed out: first, cells have responded to freshly prepared solutions, second, only when they were intoxicated by EC25 (figure 6) and not by $\mathrm{EC}_{0} \mathrm{CdCl}_{2}$ toxic solution (figure 7). Relating to the first point, some authors [22-23] mention that when high diluted solution is not freshly prepared, it is suggested to agitate it before the use in experiment. Concerning to EC25 and EC50 $\mathrm{CdCl}_{2}$ solutions effect on LLC-PK1, a hypothesis was formulated: the pre-treatment with $\mathrm{CdCl}_{2} \mathrm{HD}$ conduct cells to respond effectively to a sublethal toxic concentration (EC25), but can not conduct cell response in a more expressive intoxication (EC50).

The $\mathrm{CdCl}_{2} \mathrm{HD}$ solution protection in these cells intoxicated by the same metal may be acting in the cell mechanisms related to the ability of cell to recover to damage and/or to protective mechanisms.

A known fact in literature that corroborates is the intrinsic ability of the epithelial renal cells to repair sublethal drugs damages. One of the first organ to be in touch with several drugs or chemicals is the kidney because it has a high blood flow rate and because of the presence of cellular transport systems that facilitate concentration of these compounds within the nephron epithelial cells. When chemical injury happens, the tissue responds dynamically and, when possible, repair occur rapidly. The repair potential decreases when cells receive a constant insult [24].

Importantly, Pfaller and Gstraunthaler mentioned in their paper: "as long as cell damage is below a certain threshold or is sublethal, functional disturbance may become measurable only if sensitive enough methodologies are applied". This affirmation allows a question about the application of MTT assay in this study: would we detect the protective effect of $\mathrm{CdCl}_{2} \mathrm{HD}$ when intoxicated by $\mathrm{CdCl}_{2}$ EC50 solution using a more sensitive technique?

Regards to cell damage, it has been described in literature the cellular stress responses and molecular mechanisms of nephrotoxicity and the mechanisms of $\mathrm{Cd}^{+2}$ intoxication effect on kidney cells [25]. Cadmium stimulates the synthesis of detoxifying proteins, such as metallothionein (MT) and heat-shock proteins (HSPs). Metallothionein bind in transition metals offering a protective role against DNA oxidative damage, and heat-shock proteins is a family of cellular stress proteins that are induced after oxidative stress and help to prevent tissue damage. Induction of HSPs is generally considered as an adaptive response of cells to stress, linked to cell survival. The expression of HSP70, in particular, has been shown to be a potential early marker of toxic exposure [10] [26].

Gennari and colleagues [10] published a very interesting study. They verified a range of $\mathrm{CdCl}_{2}$ concentrations with intoxication effect on LLC-PK1 cells during $24 \mathrm{~h}$. This experiment revealed an increase in HSP70 expression on LLC-PK1 cells when they received $25 \mu \mathrm{M}$ of $\mathrm{CdCl}_{2}$. A slight expression of the MT protein is evident after exposure to $25 \mu \mathrm{M}$ of $\mathrm{CdCl}_{2}$, while MT is highly expressed after $50 \mu \mathrm{M} \mathrm{CdCl} 2$ and is located especially inside and around the nuclei.

Moreover, they observed cytoskeleton alteration, as the cleavage of actin filaments after exposure to $25 \mu \mathrm{M}$ $\mathrm{CdCl}_{2}$ and the classical formation of stress fibres, clearly indicating damage to the normal cytoskeletal organization. At $50 \mu \mathrm{M}$ of $\mathrm{CdCl}_{2}$ the cells presented a complete depolymerization of the actin organization and the nuclei indicated DNA fragmentation. These results present evidences of molecular mechanisms involved in sublethal and lethal $\mathrm{CdCl}_{2}$ intoxication doses. Even with the dynamic cell stimulation to respond to the drug insult, the dose concentration of cadmium induce other cells changes as DNA fragmentation, decrease in the DNA repair system, enhances oxidative stress, causes mitochondria injuries, and others effects [1].

Considering the results of the present work, $\mathrm{CdCl}_{2} \mathrm{HD}$ solutions may be inducing the synthesis of detoxifying proteins, as the basal MT does not mediate resistance to cadmium in mouse and human cells, however, the induction of MT can increase resistance to cadmium [27], then, in this way, $\mathrm{HD} \mathrm{CdCl}_{2}$ would avoid the deleterious effects of the cadmium. 


\section{Conclusion}

The present study has identified a protective effect of two $\mathrm{CdCl}_{2}$ high diluted solutions, $10 \mathrm{cH}$ and $20 \mathrm{cH}$, when cells were intoxicated by sublethal $\mathrm{CdCl}_{2}$ concentration. The results indicate that probably the high dilutions have an expressive action on cells in sublethal intoxication, avoiding the deleterious effects of the cadmium. The perspective on this project is to verify the probable steps where $\mathrm{CdCl}_{2} \mathrm{HD}$ acts on early sublethal $\mathrm{CdCl}_{2}$ intoxication on LLC-PK1 cells, focusing on the adaptive cell response stage as the synthesis of stress response proteins- MT and HSP.

\section{References}

[1] Bertin G, Averbeck D. Cadmium: cellular effects, modifications of biomolecules, modulation of DNA repair and genotoxic consequences (a review). Biochimie. 2006; 88: 1549-1559.

[2] Friberg L. Cadmium and the Kidney. Environ Health Perspect. 1984; 54: 1-11.

[3] Blumenthal S, Lewand D, Krezoski SK, Petering DH. Comparative Effects of Cd2/ and Cd-Metallothionein on Cultured Kidney Tubule Cells. Toxicol Appl Pharmacol. 1996; 136: 220-228.

[4] Prozialeck WC, Edwards JR, Lamar PC, Smith CS. Epithelial barrier characteristics and expression of cell adhesion molecules in proximal tubule-derived cell lines commonly used for in vitro toxicity studies. Toxicol In Vitro. 2006; 20: 942-953.

[5] Hull RN, Cherry WR, Weaver GW. The origin and characteristics of a pig kidney cell strain, LLC-PK. In: In Vitro Cellular \& Developmental Biology- Plant. Springer Berlin: Heidelberg; 1976; 12 (10): p 670-677.

[6] Boogaard PJ, Nagelkerke JF, Muller GJ. Renal proximal tubular cells in suspension or in primary culture as in vitro models to study nephrotoxicity. Chem Biol Interact. 1990; 76: 251-292.

[7] Gstraunthaler G, Steinmassl D, Pfaller W. Renal cell cultures: a tool for studying tubular function and nephrotoxicity. Toxicol Lett. 1990; 53: 1-7.

[8] Olabarrieta I, L’Azou B, Yuric S, Cambar J, Cajaraville MP. In vitro effects of cadmium on two different animal cell models. Toxicol In Vitro. 2001; 15: 511-517.

[9] Barrouillet MP, Ohayon-Courtès C, Dubus I, L`Azou L, Nguyen Ba C. Influence of cadmium speciation for the evaluation of in vitro cadmium toxicity on LLC-PK1 cells. Toxicol In Vitro. 2001; 15: 525-529.

[10] Gennari A, Cortese E, Boveri M, Casado J, Prieto P. Sensitive endpoints for evaluating cadmium-induced acute toxicity in LLC-PK1 cells. Toxicology. 2003; 183: 211-220.

[11] Delbancut A, Merlet D, Mellado M, Dorfman P, Cambar J. Ètude de L'effet Protecteur de Très Hautes Dilutions de Cadmium vis-à-vis de Concentrations Cytotoxiques de ce Même Métal sur des Cultures Cellulaires Rénales. Cahiers de Biothérapie. 1993 Février-mars; 120: 39-44 [French].

[12] Farmacopéia Homeopática Brasileira. 2nd ed. São Paulo: Atheneu; 1997. [Portuguese]

[13] Fontes OL. Farmácia Homeopática: Teoria e Prática. São Paulo: Manole; 2001. p. 353. [Portuguese] 
[14] Mossman T. Rapid colorimetric assay for cellular growth and survival: application to proliferation and cytotoxicity assay. J Immunol Methods. 1983; 65: 55-63.

[15] Gerlier D, Thomasset N. Use of MTT colorimetric assay to measure cell activation. J Immunol Methods. 1986; 94: 57-63.

[16] Twentyman PR, Luscombe M. A study of some variables in a tetrazolium dye (MTT) based assay for cell growth and chemosensitivity. Br. J. Cancer. 1987; 56: 279-285.

[17] Buckberry LD. Cytotoxicity Testing Using Cell Lines. In: Methods in Biotechnology, Animal Cell Biotechnology. New York: Humana Press; 1999 Feb 22; 8: 239-252.

[18] Loveland BE, Johns TG, Mackay IR, Vaillant F, Wang Z, Hertzog PJ. Validation of the MTT dye assay for enumeration of cells in proliferative and antiproliferative assays. Biochem Int. 1992 july; 27(3): 501-510.

[19] Supino R. MTT Assays. Methods Mol. Biol. 1995; 43:137-149.

[20] Morgan DML. Tetrazolium (MTT) Assay for Cellular Viability and Activity. Methods Mol Biol. 1998; 79: 179-83.

[21] [Author unknown]. Introducing dose-response curves [online]. place unknown: publisher unknown; updated 2010 Mar 14; [cited 2010 Mar 14]. Available from:

http://www.graphpad.com/curvefit/introduction89.htm

[22] Cristea A, Nicula S, Darie V. Pharmacodynamic effects of very high dilutions of Belladonna on the isolated rat duodenum. In: Bastide M (editor). Signals and Images. Dordrecht: Kluwer; 1997, p. 161-170.

[23] Bonamin LV, Martinho KS, Nina AL, Caviglia F, Do Rio RGW. Very high dilutions of dexamethasone inhibit its pharmacological effects in vivo. Br Homeopath J. 2001; 90: 198-203.

[24] Pfaller W, Gstraunthaler G. Nephrotoxicity Testing in vitro- What we know and what we need to know. Environ Health Perspect. 1998 april; 106 (2): 559-569.

[25] van de Water B., de Graauw M., Le D’ev'edec S., Alderliesten M. Cellular stress responses and molecular mechanisms of nephrotoxicity. Toxicol Lett. 2006; 162: 83-93.

[26] Bonham RT, Fine MR, Pollock FM, Shelden EA. Hsp27, Hsp 70, and metallothionein in MDCK and LLCPK1 renal epithelial cells: effects of prolonged exposure to cadmium. Toxicol Appl Pharmacol. 2003; 191: 6367.

[27] Kennette W, Collins OM, Zalups RK, Koropatnick J. Basal and zinc-induced metallothionein in resistance to cadmium, cisplatin, zinc, and tertbutyl hydroperoxide: studies using MT knockout and antisensedownregulated MT in mammalian cells. Toxicol Sci. 2005; 88: 602-613.

\section{Efeito protetor do Cloreto de Cádmio altamente diluído sobre células LLC_PK1} intoxicadas por altas concentrações desse metal: um ensaio isopático in vitro.

\section{RESUMO}


O Cádmio é um contaminante ambiental relevante. Muitos estudos demonstram que o sítio de toxicidade em humanos e outros animais é o túbulo proximal do rim. Um modelo bem estabelecido para nefrotoxicidade é o uso de técnicas in vitro com linhagens de células epiteliais do túbulo proximal, conhecidas por LLC-PK1. Assim, nossa proposta foi a de estudar os eventuais efeitos protetores de uma alta diluição de $\mathrm{CdCl}_{2}$. $\mathrm{Em}$ um ensaio cego, células LLC_PK1 foram pré-tratadas com altas diluições de cloreto de cádmio nas diluições $10 \mathrm{cH}$, $15 \mathrm{cH}$ e $20 \mathrm{cH}$. Após 4 dias, estas células receberam $\mathrm{CdCl}_{2}$ em uma concentração tóxica, previamente deteminada. A viabilidade cellular foi estudada por ensaios MTT. Observamos um efeito protetor para duas altas diluições de $\mathrm{CdCl}_{2}, 10 \mathrm{cH}$ e $20 \mathrm{cH}$, quando as células foram intoxicadas por concentrações subletais de $\mathrm{CdCl}_{2}$. Estes resultados indicam a possibilidade de que altas diluições tenham ação expressiva em células, em intoxicações subletais.

Palavras-chave: toxicidade, Cádmio, Alta Diluição, Isopatia, Adaptação celular

\section{Efeito protetor do Cloruro de Cádmio altamente diluido sobre células LLC-PK1 intoxicadas por alta concentración de este metal: un ensayo isopático in vitro.}

\section{RESUMEN}

El Cádmio es un metal pesado com relevante acción tóxica en el medio ambiente. Varios estudios han demostrado que un sitio importante de la toxicidad del cadmio en los humanos y en otros animales es el túbulo proximal del riñón. Un modelo bien establecido de nefrotoxicidad es el uso de la técnica in vitro con células epiteliales del túbulo proximal, como las LLC-PK1. Estudiamos el posible efecto protector de soluciones altamente diluidas de $\mathrm{CdCl}_{2}$. Com uma metodologia em ciego, las células LLC-PK1 fueron pretratados con cloruro de cadmio altamente diluídos en las potencias $10 \mathrm{cH}, 15 \mathrm{cH} \mathrm{y} 20 \mathrm{cH}$. Después de 4 días, estas células han recibido $\mathrm{CdCl}_{2}$ en una concentración tóxica predeterminado. La viabilidad celular se evaluó por el ensayo MTT. Hemos identificado un efecto protector de dos soluciones de altamente diluída de $\mathrm{CdCl}_{2}$, $10 \mathrm{cH}$ y $20 \mathrm{cH}$, cuando las células se intoxicaron por concentración $\mathrm{CdCl}_{2}$ subletales. Los resultados indican que probablemente las altas diluciones tienen una acción expresiva en las células, en la intoxicación subletal.

Palabras-llave: toxicidad, Cadmio, Altas Diluciones, Isopatia, Adaptación celular.

\section{(cc) BY-NC-ND Licensed to GIRI}

Support: authors declare that this study received no funding

Conflict of interest: authors declare there is no conflict of interest

Received: 19 February 2010; Revised: 22 March 2010; Published: 31 March 2010.

Correspondence author: Roberta Ghilosso-Bortolini, rgbortolini@gmail.com

How to cite this article: Ghilosso-Bortolini R, Bonamin LV, Holandino C. Putative protective effect of Cadmium chloride high diluted solution on LLC-PK1 cell intoxicated by high concentration of this same metal: an isopathic in vitro assay. Int J High Dilution Res [online]. 2010 [cited YYYY Month dd]; 9(30): 16-29. Available from:

http://www.feg.unesp.br/ ojs/index.php/ijhdr/article/view/381/421 